\title{
An exploratory critique of the notion of social cohesion in contemporary South Africa
}

\section{[R E F L E C T IO N S ]}

\section{Abstract}

This article seeks to situate the increasing salience of social cohesion in the context of the transition from apartheid to a post-apartheid society. It first part of the article focusses on the changing political and economic landscape post 1990. It pays particular attention to the role of Nelson Mandela as a symbol of national unity. While the fact that the African National Congress (ANC) government's economic policies under his leadership failed to have a fundamental impact on levels of poverty and inequality, Mandela's stature and ability to reach out to different constituencies created the conditions for him to be seen as a great unifier. His successors Thabo Mbeki and Jacob Zuma have also not had much success at the level of alleviating high levels of poverty and inequality while also not enjoying the same iconic status of Mandela. Starting in the Mbeki era but gaining momentum under the Zuma Presidency, the country has witnessed rising levels of community and labour unrest. In this context, the article argues that notions like social cohesion and ubuntu have assumed increasing importance as ways to stitch together a fracturing society. The latter part of the article argues that, with high levels of poverty and inequality, commodification of basic services and mounting social protests, it is difficult to deploy ideas like social cohesion, especially when new militant political subjectivities are challenging the hegemony of the ANC.

\section{New beginnings}

In 1990, the liberation movements in South Africa were unbanned and Nelson Mandela strode out of prison. In one bold stroke, the country's political

\author{
Ashwin Desai \\ Department of Sociology, \\ University of \\ Johannesburg \\ ashdesai1@gmail.com
}

\section{Keywords:}

Social cohesion, ubuntu, South Africa, post-apartheid society, xenophobia 
landscape changed. The African National Congress (ANC) led negotiations with the apartheid regime and within four years, Nelson Mandela was inaugurated as the first democratically elected President of South Africa. The declared goals of progressive organisations and individuals in the immediate years after the unbanning of the ANC were the building of non-racialism and overcoming apartheid's legacy. Mandela's release and subsequent endorsement of the Freedom Charter encouraged expectations of speedy and fundamental changes in South Africa's political economy. But soon, the ANC leadership, sobered by the collapse of the Soviet Union, made a series of concessions that essentially left the commanding heights of the economy intact (Marais, 2011).

Words like pragmatism and the practical realities of managing the economy quickly replaced the high-sounding promises of the Freedom Charter. Transformation, it was held, had to occur with due regard for white fears of being swamped and the attendant capital flight and skills deficit which those taking over the reins of power would have to confront.

Alongside this, the ANC government-in-waiting was keen on the demobilisation of a range of strident mass movements, which they held espoused radical but "unsustainable" visions of social change. The emphasis was on stability and creating the necessary conditions for a negotiated settlement (Alexander, 2002).

At a general level, demobilisation was accompanied by attempts at de-politicisation and change as a set of technical issues and targets to be met. Conflict, as Harold Wolpe (1995: 97) pointed out, was to be kept to a bare minimum, with debates around the nature of transformation and the imperative of restructuring "immediately offset by dissolving the differences into the goals".

The ANC was keen to suture the local economy into the rhythms of global capitalism. In their analysis, this swift normalising of relations would pave the way for foreign investment, fuelling economic growth and acting as the bridgehead for deeper societal transformation through a myriad of reconstruction and development programmes (Saul \& Bond, 2014).

A country that witnessed sustained mobilisation throughout the 1980 s began to see significant changes. The ANC absorbed the Mass Democratic Movement; the union movement accepted the leadership of the ANC in the hope that an alliance would secure major legislative concessions; many civic organisations, when not acting as voting banks for councillors, doubled as ANC branches. Stability was the watchword everywhere. 
In thinking through the transition, we need to keep in mind two broad approaches that can broadly be labelled "reformative" and "transformative". ${ }^{1}$ The transformative project sought to fundamentally transform the way in which society was structured; its economic emphasis was captured in the popular slogan "growth through redistribution", a bottom-up, mass based approach. The reformative approach, on the other hand, prioritised reconciliation and cooperative governance in the interests of economic growth and acceptance into a neoliberal world order. In this scenario, conditions suited to facilitate an environment for doing business in South Africa would be created. The logic underlying this paradigm was that the benefits of economic growth would "naturally" trickle down to the poorest members of society, encapsulated in the adage "redistribution through growth". State intervention would help to de-racialise the uppermost reaches of the class hierarchy through the pursuit of Black Economic Empowerment (BEE).

It was the reformative project that won hegemony as the transition to democracy unfolded; its' "twin objectives of restoring business confidence and attracting foreign investment seemed to swamp all other considerations" (Murray, 1994: 24). However, this didn't mean that attempts were not made to integrate the reformative and transformative approaches, encapsulated in the "two economies" thesis. In 2003, President Thabo Mbeki characterised South African society as divided between first and third world components. For Mbeki, the "first world economy" was "structurally disconnected" from the "third world economy". Mbeki argued that the solution lay in the tweaking of the neoliberal approach so that government intervention could support "the development of the 'third world economy' to the point that it loses its 'third world' character and becomes part of the 'first world economy"' (Mbeki, 2003).

The ANC's Reconstruction and Development Programme (RDP) was hollowed out and replaced by the Growth, Employment and Redistribution (GEAR) plan, announced in 1996. At the core of GEAR was the fostering of conditions for the accumulation and profitability of capital. The state, it was argued, would redress apartheid's legacy through taxes geared towards reconstruction and development and the extension of grants. In addition, the entry of new Black entrepreneurs through economic empowerment imperatives would progressively de-racialise the upper echelons of the economy. And a small black elite did start to emerge, as well as a growing Black middle class. While this was celebrated as an indication of gains made in the first decade of the transition, at the same time, it served to heighten the fact that the poorest of the poor hardly saw an advance in their economic condition.

For a fuller exposition of these ideas, see Desai, A (ed) (2010) The race to transform: Sports in post-apartheid South Africa. Cape Town: HSRC Press. 
The transition to democracy and the economic programmes that unfolded failed to make an impact on levels of poverty and inequality. As former Robben Island prisoner Neville Alexander put it in 2002: "The stark reality is that the political settlement of 1993-94 was based ... on the assumption of a more or less rapid trickle-down effect deriving from the 'miraculous' increase in the rate of the GDP ...The real situation is that hardly any change has taken place in the relations of economic power and control. Moreover, in the foreseeable future and in terms of the prevailing system, no such fundamental change is to be expected. With hardly any exceptions, the sources of economic power remain in hands that controlled them under apartheid" (2002: 144-46).

While a small, super rich black elite and a black middle class centred mainly in the civil service and the lucrative world of tenderpreneurship emerged, the years post 1994 saw unemployment increase and inequality deepen (Marais, 2011). The state of South Africa's economy was outlined by the United Nations Development Programme (UNDP) in unusually blunt language: "... highly skewed distribution of wealth; an extremely large earnings inequality; weak access to basic services by the poor, unemployed and underemployed; a declining employment outcome of economic growth; environmental degradation; HIV/AIDS, and an inadequate social security system" (2003: 90). While the transition can be narrated in hard economic terms, there was also the factor of Madiba (Mandela). It was a powerful time of hope in South Africa.

\section{Madiba magic}

With Mandela at the helm, it was a time of embracing, of grand gestures, of style and the possibility of everyday freedom, whatever the structural and historical constraints. Mandela for example, saw sport as a powerful weapon, to not only heal racial divisions, but also to smooth the way for South Africa's entry into the comity of nations. So even while negotiations were on-going and the apartheid National Party held power, Mandela sanctioned South Africa's participation in the Cricket World Cup and the 1992 Olympics. The 1995 victory at the Rugby World Cup, with Mandela resplendent in a Springbok jersey, was received with global acclaim. This was followed by the winning of soccer's African Cup of Nations.

It was at this time that the idea of Madiba Magic caught the public imagination and a belief that something exceptional was being born in South Africa (Lodge, 2003). Mandela was seen as the "magnanimous sorcerer" and his actions and statements "acquired a providential hue" (Cabrujas, in Coronil, 1997: 1). There was a deep sense that Madiba Magic would conjure an audacious spell, propelling the country into the global economy while ensuring local levels of upliftment and redistribution.

It signalled a time when those who suffered under the yoke of apartheid would take their place as fully-fledged citizens under a new flag and national anthem, guided by a 
new constitution in a new South Africa. Mandela marked the closure of one long terrible worldwide history, defined by colonial dispossession and racial oppression. At the same time, he signalled an opening; of a time when all South Africans would be free from racial and economic exclusions, blessed to be living under the benevolent gaze of the "Rainbow Nation of God."

The coming to power of Thabo Mbeki saw a renewed commitment to advancing the transformation agenda through a series of policy interventions. But they failed to make a dent in the levels of inequality and poverty. And when Mbeki gave way to Jacob Zuma, expectations were fuelled of a radical change in policy that would drive a redistribution programme. These expectations were once more sacrificed on the altar of economic "realities".

On the ground, there were increasing levels of violent protest. Fractures in the ruling party, as cadres jostled for position and tensions within the Alliance and the expulsion of the powerful National Union of Metalworkers (NUMSA) from COSATU, only served to highlight the fact that any ideas of blossoming nationhood were faltering (Satgar \& Southall, 2015). It seemed light years away from the glow of the Mandela years.

In this context of fragmentation and division, the government has emphasised the importance of a socially cohesive society. In the next section, we look at this idea and try to discern what is meant by social cohesion.

\section{Social cohesion - a magic balm?}

In the face of mounting divisions and fault-lines in South African society, the government, supported by civil society and the private sector, has placed great faith in the idea of social cohesion. National and provincial summits are convened to explore the topic. In almost every national and provincial policy document, the phrase 'social cohesion' is reiterated and emphasised. It is as if some new magic balm has been invented that will be able to glue Alexandra with Sandton, Cecil John Rhodes with Nelson Mandela, Mohandas Gandhi with Eugene de Kock, Cyril Ramaphosa with the 34 murdered miners at Marikana, the Catholic Archbishop with the Gay and Lesbian lobby.

So what exactly is social cohesion? One gets definitions like this from the Department of Arts and Culture: "The degree of social integration and inclusion in communities and society at large, and the extent to which mutual solidarity finds expression itself among individuals and communities. In terms of this definition, a community or society is cohesive to the extent that the inequalities, exclusions and disparities based

\footnotetext{
The phrase "rainbow nation" was first used by Archbishop Desmond Tutu in 1994 in a series of televised appearances.
} 
on ethnicity, gender, class, nationality, age, disability or any other distinctions which engender divisions distrust and conflict are reduced and/or eliminated in a planned and sustained manner" (DAC, 2012).

This definition lends itself to more questions than answers. What constitutes a community? Who decides on the plan to reduce inequality? What if the state's plans exacerbate inequality? When is discrimination deemed to be positive or negative? For example, affirmative action focuses on race and reinforces race thinking, yet at the same time, it is a tool to redress past discrimination.

According to Cloete and Kotze (cf 2009: 7), and based on Jensen's 1998 study, social cohesion consists of five dimensions:

- Belonging: To be part of and to experience a sense of affiliation to the community and the larger society. It involves processes of identification and acceptance within a community and larger society. In a diverse society such as South Africa, it requires identification with and acceptance of groups.

- Inclusion: To be included on an equal basis in all social activities and rights and to have equal access to all life opportunities.

- Participation: This, unhindered, means active involvement in community and social activities, programmes and events.

- Recognition: To recognise, acknowledge and value differences without discrimination.

- Legitimacy: Refers to the integrity and social legitimacy of public bodies and leaders representing community members and citizens.

Again, each one of these dimensions is open to interpretation. "To be included on an equal basis" demands an equal playing field. And if that doesn't exist, how does one decide what should be done to compensate? For example, in a cricket team, should a quota system make place for three players of colour or four? And can one really avoid policies like quotas that undoubtedly create tensions and divisions?

Demanding equality for township spaza shop-owners squeezed out by competition from Somali entrepreneurs, South African Minister for Small Business Development, Lindiwe Zulu, demanded that Somalis share their trade secrets with locals to ensure they are accepted in the communities (Business Day, 28 January 2015). Suddenly the foreign 
shopkeepers were turned into a sect akin to witches, who if they did not reveal their magic formula, would be sent on their way. It is a far cry from the four key pillars of "diversity, inclusiveness, access and values" espoused at a Social Cohesion summit held in 2012. The Department of Arts and Culture holds that social cohesion is based on the following principles:

- Constitutional Democracy

- Human Rights and Equality

- Non-racialism, Non-tribalism and Non-sexism

- Unity in Diversity

- Inclusivity and Social Justice

- Redress and Transformation

- Intergroup and Community Co-operation

- Social Solidarity

- Active and Participatory Citizenship

- Civic Responsibility

- National Consciousness

These principles are replete with contradictory impulses. To develop a national consciousness is to create boundaries with "outsiders". To pursue race-based redress that uses apartheid categories is to work against non-racialism. What will constitute civic responsibility or active citizenship? Is taking part in protests a form of active citizenship or is it to be reduced to waving the national flag?

And social solidarity with whom? A spontaneous march of middle class suburbanites took place in April in Port Elizabeth after the tragic abduction and killing of a beloved school teacher. They demanded an end to savagery and called for the death penalty. In their minds, against which spectre were they truly marching? The question is relevant because social mobilisation dimmed considerably when the white husband was arrested (Times Live, 3 May 2015). 
At the government's Social Cohesion Summit held in March 2015, Minister Nathi Mthethwa said that "Social cohesion will only succeed through all round and interconnected efforts for social progress which will change material conditions of the populace for the better. It means the total transfer of political and economic power to the democratic majority" (Social Cohesion Summit, Port Elizabeth, 30 March 2015). What does Minister Mthethwa, the Minister of Police at the time of the Marikana massacre, mean by "total transfer"? After all, his Party is dedicated to private ownership of the means of production. What does a "democratic majority" mean? Those who vote or ally themselves with minority parties will be left out of the redistribution dividend? In thinking through the many meanings of social cohesion, one is reminded of Clifford Geertz's phrase, "The stultifying aura of conceptual ambiguity" (1973: 257). In South Africa, the idea of social cohesion is tied to ubuntu.

\section{Ubuntu}

Thabo Mbeki was one of the first leaders to bring together the idea of social cohesion and ubuntu: "a person is a person through other persons", emphasising co-operation rather than conflict and encouraging mutual understanding and tolerance, holding that "Our society has been captured by a rapacious individualism which is corroding our social cohesion, which is repudiating the value and practice of human solidarity, and which totally rejects the fundamental precept of Ubuntu" (Mbeki, 2007: 16). Some would argue that the railing against rapacious individualism was a bit rich coming from Mbeki, given that he was keen to develop a black bourgeoisie and whose economic policies were fingered for exacerbating inequality and poverty.

But to mitigate poverty and inequality, there is always ubuntu. Ubuntu is given a deep history dating back to pre-colonial times according to the Department of Arts and Culture: "In the context of South Africa, it may be said that a concern with social cohesion dates even further back to the advent of colonialism and its disruptive and destructive effects of dispossession and exclusion on local communities and society at large, as well as the social upheavals this system spawned. The issue of social cohesion was pertinent throughout the 20th century in the wake of urbanisation and forced removals. Modern nation-building, on the other hand, dates back to the struggles for national liberation in the 19th century which saw a spirit of nationalism inspired by struggles for independence across the globe. So, just as the disintegration of local communities dates back to the violent contact of local communities with advancing colonists, the South African struggle for national liberation and national unity is not something new or recent" (2012: 30).

So, what we have is a pristine, placid society that becomes corrupted with the advent of colonialism. However, as Christoph Marx points out, it is important to discern how 
ubuntu can be deployed in present day South Africa: "Chiefs are able to treat Ubuntu and nation building as a tradition-oriented project, and to resume seamlessly the legitimation patterns of apartheid ... the other side of communalism is unfolding gradually: a suppression of individual freedom, pressure to behave in a conformist manner, convulsive conservatism, and the exclusion of both inner-party and external critics. The message is clear: whoever resists the power of the Chiefs is a traitor to his own culture, i.e. to the nation. 'Tradition' and 'culture' have even been used to legitimise discrimination and (rapidly increasing) violence against women" (2002: 63).

Ubuntu, by emphasising some ideal pre-colonial past and the use of ethno-cultural inflections only serves to reinforce the power of chiefs, cuts off critical thinking and could be used to discriminate and exclude rather than develop social cohesion.

Using the example of the lauding of home/community based care by the state in the case of HIV/AIDS patients, Hein Marais (2005) shows how neo-liberalism (with its demand for less and less state support in public health and emphasis on privatisation) and ubuntu fit snugly with each other. He writes: "To pretend that home- and communitybased care express a reanimated social solidarity that can supplant the logic and the ethics of the market is to miss the plot entirely. While the well-being of the poor becomes ever more precarious, additional burdens are being shifted onto them. Celebrating this as an expression of hardiness and vim, an affirmation of ubuntu, seems morally base. In practice, home-and community-based care displaces much of the burden of care into the 'invisible' zones of the home and the neighbourhood - and specifically onto women, most of them poor, many of them desperately so" (Marais, 2005: 67).

Capitalism not only hurries in new production relations but also new commodities. Mandela, in the first visit to his village in Qunu after release from three decades in prison, writes hauntingly of how the arrival of commodities had affected the environment and social relations of the area: "When I was young, the village was tidy, the water pure, and the grass green and unsullied as far as the eye could see. Kraals were swept, topsoil was conserved, fields were neatly divided. But now the village was unswept, the water polluted, and the countryside littered with plastic bags and wrappers. We had not known of plastic when I was a boy, and though it surely improved life in some ways, its presence in Qunu appeared to me to be a kind of blight. Pride in the community seemed to have vanished" (Mandela, 1994: 581). Imagine what two decades of Mandela capitalism has unleashed on the countryside? In the context of the deepening of capitalist relations and commodification of basic services, ubuntu is seen as the way to ensure social cohesion.

It is raised at every possible opportunity. In the aftermath of the xenophobic attacks of 2015, Amanda Gcabashe entered the debate with an article in Business Day (17 April 
2015) entitled "We need to revive the principles of Ubuntu". For her, the way to counteract xenophobia was to return to the "forgotten principles of Ubuntu - a pointer to the value of human life in African culture."

According to Gcabashe, there have been no attacks on "'foreign' businesses ... under tribal authority." This is because "registration is carried out the traditional way - by the community according to norms they agreed to ... not by councillors and administrators who do not understand the community dynamics."

Gcabashe then goes on to explain how her family recently acquired land outside Pietermaritzburg: "Before the transaction was finalised, we had to have a referral letter from someone attesting to our character. After the chief accepted this letter, the headman of the chief had to introduce us to the community around us at a formal ceremony. It is only after these processes had been completed that we could proceed and assume ownership of the land we bought. We did not parachute in from out of town nor were we assigned land in a secret deal between ourselves and the seller. Contrast this with the allocation of RDP houses, which is done out of sight of the community. How many times have we heard of community protests because houses are allocated to 'outsiders'?"

By following precepts that hark back to pre-colonial times, we can "build social cohesion and prosperity", according to Gcabashe. In Gcabashe's worldview, the way to deal with xenophobia is to give the headman and communities the authority to decide who fits in and who does not, who is an outsider and who deserves to be allocated houses. One is reminded of Belinda du Plooy's warning that ubuntu can "lead to oppressive, stifling conformity ... tribalistic exclusion, hierarchical patriarchal relations ..." (2014: 92). With government targets missing the mark, its own legitimacy under attack and people eschewing institutions for the streets, one can see why the ANC is keen on social cohesion. It allows for social cohesion to function as a means of cutting off dissent and imposing conformity.

\section{Between cohesion and capitalism}

Social cohesion is better than social conflict, it could be argued. But this is to elide the daily violence of the poor that ensures life is "nasty, brutish and short" (Hobbes, 1960: 82). The rich develop social cohesion through Chambers of Commerce and gated communities. They work out the rules of engagement and settle their differences through expensive litigation. The poor take to the streets to demand delivery. Workers go on strike to demand a living wage. Within a liberal democracy, it is these recalcitrant, noisy, impatient, some would even argue ungrateful citizens whom the ruling classes believe need a healthy dose of social cohesion. 
In thinking through words like social cohesion and the resurrection of ubuntu in the context of the ANC's deepening capitalism, even shooting mine-workers to ensure maximum profit, as was suggested in the Farlam Commission, one is reminded of Orwell's definition of doublespeak: "In our time, political speech and writing are largely the defence of the indefensible... Thus political language has to consist largely of euphemism, question-begging and sheer cloudy vagueness ... The great enemy of clear language is insincerity. Where there is a gap between one's real and one's declared aims, one turns as it were instinctively to ... exhausted idioms ..." (Orwell, 1969: 153-154).

Social cohesion demands that no matter what the provocations of the state, we must look for ways to come together and believe in their sincerity. This is problematic in many ways. Not least of which, as Gregersen points out, is that in liberal democracies, social cohesion demands coercion and "cohesion policies seem inappropriate for dealing with all political issues, such as the underlying distribution of power and recognition that determine the social distribution of goods and rights" (Gregersen, 2013: 88).

Social cohesion is a tool in which the state wants to condition us so that we begin to act not as critical subjects but in a Pavlovian way. They seek to achieve this not by authoritarianism but through the inculcation of a belief that dissent and protest are against the national interest. As Gregersen (2013: 88) points out: "The meaning of 'SC' approximates 'good society' in the political discourse. Justifications for cohesion policies thus resemble tautologies: One should promote a good society because it is good. Correspondingly, policies contrary to SC are predefined as bad". In South Africa, this means that proponents of social cohesion seek to manage antagonism at precisely the point when we need robust political engagement, political analysis and political action. One is reminded of Foucault's idea of governmentality as seeking to determine "the conduct of conduct" (in Brown, 2006: 5). Social cohesion seeks to depoliticise, which as Brown (2006: 15) points out: "involves removing a political phenomenon from comprehension of its historical emergence and from a recognition of the powers that produce and contour it. No matter its particular form and mechanics, depoliticization always eschews power and history in the representation of its subject". Despite attempts to deploy ideas like social cohesion to draw people into supporting programmes such as the National Development Plan, insurgent protests spanning both community and labour keep bubbling (Brown, 2015).

\section{Challenge from below}

The last three years in South Africa have seen unprecedented countrywide protests ranging from lack of service delivery to university education fees. Alongside this, the model of creating a Black elite and the hopes that this burgeoning wealth will trickle downwards have come under sustained attack. 
During the Mandela and Mbeki years, and despite reports of rising inequality, there was a sense that the fruits of liberation were slowly ripening and would soon fall to those most in need. Recently however, there has been a questioning of the thesis that democracy will encourage the market to progressively level the playing fields. Protests over the lack of basic services have escalated and turned more violent. The state has responded with apartheid-style repression, most dramatically shooting dead 34 striking miners at Marikana.

In the interim, a new political party, the Economic Freedom Fighters (EFF) has emerged, proclaiming a radical economic policy, and garnering some one million votes in the 2014 national elections. The National Union of Mineworkers (NUMSA), forced out of the Congress of South African Trade Unions (COSATU), is seeking to sponsor a United Front, demanding an end to what it labels the ANC's anti-poor economic policies. As Achille Mbembe has put it: "Rainbowism and its most important articles of faith-truth, reconciliation and forgiveness-is fading. Reduced to a totemic commodity figure mostly destined to assuage whites' fears, Nelson Mandela is on trial. Some of the key pillars of the 1994 dispensation-a constitutional democracy, a market society, non-racialism-are also under scrutiny. They are now perceived as disabling devices with no animating potency, at least in the eyes of those who are determined to no longer wait. We are past the time of promises. Now is the time to settle accounts" (2015).

Meanwhile, South Africa hurtles towards the general election of 2019. The ANC faces changes to its leadership with a new President to be elected in 2018. With factionalism and regionalism on the rise, boardroom deal-making abounds. The Democratic Alliance, with a new Black leader, strains against its image as defender of white privilege while making ground in the townships, once ANC strongholds. On the left, the EFF has overtaken the South African Communist Party as embodiment of the hope that there will be a second stage to the South African revolution, one where peasant and proletarian ascend.

Perhaps we are at the point that William Gumede (2013) writes about? "South Africa is entering the 20-year post-liberation mark when many African liberation governments turned governments, who fail to deliver adequately on promises, either break-up, splinter or fragment when members and supporters leave it for new parties. The tipping point has been reached where the gap between the ANC leadership and the daily grind of ordinary members may have now become such a wide gulf that many ANC members who may have deep affinity with the party may now not be able anymore to identify themselves with both the leaders and the party". 
With these issues in mind, will the ANC be able to re-invent itself in a way that recaptures the ground it has lost to the left? Signs already abound. In the July 2015 "lekgotla" of the ANC's national executive committee, general secretary Gwede Mantashe made the point "that high unemployment, deepening poverty and growing inequality pose a real threat in the long term", as he questioned policies that allowed South African companies to list on the London Stock Exchange, throwing into sharp relief the ANC's Faustian pact with global finance and local capital (The Star, 7 August 2015).

Will the present government rely on a combination of building a Black middle class alongside a repressive apparatus to keep discontent in check, while ratcheting up the rhetoric on issues like the composition of national sports teams and playing to the ascendancy of racial nationalism?

We live at a time when representations of the liberation struggle which produced unity are crumbling. Durkheim's words are prescient: "the former gods are growing old or dying, and others have not been born" (1995: 429). In this period of uncertainty and fracture, and in the absence of a fundamental shift in economic policy towards redistribution, attempts to keep things together with ideas like social cohesion will be increasingly hard to sustain.

\section{References}

Alexander, N (2002) An ordinary country: Issues in the transition from apartheid to democracy in South Africa. Pietermaritzburg: University of Natal Press.

\section{Brown, J (2015) South Africa's insurgent citizens: On dissent and the possibility} of politics. London: Zed Books.

Brown, W (2006) Regulating aversion: Tolerance in the age of identity and empire. Princeton: Princeton University Press.

Cloete, P \& Kotze, F (2009) Concept paper on social inclusion in local integrated development plans. Pretoria: Department of Social Development. http://www.presidentsaward.co.za/wp-content/uploads/2013/04/Social-CohesionFinal-Draftcorrect-IDP-DSD.pdf

Sotho and Tswana word for conference or business meeting. 
Coronil, F (1997) The magical state: Nature, money and modernity in Venezuela. Chicago: University of Chicago Press.

Department of Arts and Culture (2012) What is social cohesion and nation building. Pretoria: Department of Arts and Culture.

http://www.dac.gov.za/sites/default/files/WHAT\%20IS\%20SOCIAL\%20COHESION\%20 AND\%20NATION\%20\%283\%29.pdf

Desai, A (ed) (2010) The race to transform: Sports in post-apartheid South Africa. Cape Town: HSRC Press.

Du Plooy, B (2014) Ubuntu and the recent phenomenon of the charter for compassion. South African Review of Sociology, 45(1), 83-100.

Durkheim, É (1995) The elementary forms of religious life. New York: Free Press (1912).

Geertz, C (1973) The interpretation of cultures. New York: Basic Books.

Gregersen, K (2013) Assessing the glue that holds society together: Social cohesion arguments in liberal democracy. Tidskrift for Medier, Erkendelseog Formidling. Årg. 1(2), 78-94.

Gumede, W (2013) ANC fragmentation. Pambazuka News, 4 July 2013. http://pambazuka.org/en/category/features/88110

Hobbes, T (1960) Leviathan. Oxford: Basil Blackwell (1651).

Lodge, T (2003) Politics in South Africa: From Mandela to Mbeki. Indiana: Indiana University Press.

Mandela, N (1994) Long walk to freedom. Johannesburg: Macdonald Purnell. Marais, H (2011) South Africa pushed to the limit: The political economy of change. London: Zed Books / Cape Town: UCT Press.

Marais, $H$ (2005) Buckling: The impact of AIDS in South Africa. Pretoria: University of Pretoria. 
Marx, C (2002) Ubu and Ubuntu: On the dialectics of apartheid and nation building. Politikon: South African Journal of Political Studies, 29(1), 49-69.

Mbeki, T (2007). Steve Biko memorial lecture. 12 September 2007, Cape Town. http://www.polity.org.za/attachment.php?aa_id 1/47218

Mbeki, T (2003) State of the Nation address to the joint sitting of the Houses of Parliament. Cape Town, 8 February 2003.

Mbembe, A (2015) On the state of South African political life.

http://africasacountry.com/2015/09/achille-mbembe-on-the-state-of-south-africanpolitics/

Murray, M (1994) The revolution deferred: The painful birth of post-apartheid South Africa. London: Verso.

Orwell, G (1969) Inside the whale and other essays. Harmondsworth: Penguin (1957).

Satgar, V \& Southall, R (2015) COSATU in crisis. Johannesburg: KMMR Publishing.

Saul, J \& Bond, P (2014) South Africa: The present as history - from Mrs Ples to Mandela and Marikana. Suffolk: James Currey.

South African Government (2015) Minister Nathi Mthethwa: Social cohesion summit, Nelson Mandela Metropolitan University, Port Elizabeth, 30 March 2015. http://www.gov.za/speeches/minister-nathi-mthethwa-social-cohesion-summit-30mar-2015-0000

UNDP (2003) South Africa: Human Development Report.

Oxford: Oxford University Press.

Wolpe, $\mathrm{H}$ (1995) The uneven transformation from apartheid in South Africa.

Transformation, 27, 88-102. 